\title{
SEJARAH PEMUKIMAN DI KAMPUNG LALANG KOTA MEDAN
}

\author{
Oleh : \\ Pulung Sumantri \\ Rani Hartati Br. Siringo-Ringo
}

\begin{abstract}
ABSTRAK
Penelitian ini bertujuan untuk mengetahui sejarah pemukiman di Kampung Lalang, untuk mengetahui perkembangan Kampung Lalang, untuk mengetahui peranan sungai Kampung Lalang sebagai jalur transit, untuk mengetahui kehidupan sosial dan ekonomi masyarakat Kampung Lalang. Dari hasil penelitian yang dilakukan maka diketahui bahwa Kampung Lalang adalah sebuah pemukiman yang dahulunya adalah hutan dan tumbuhan-tumbuhan ilalang. Kampung Lalang dihuni oleh etnis Melayu dan suku yang paling lama ada serta bertahan hingga sekarang ini. Datuk Hitam merupakan seseorang yang memiliki banyak tanah adat dan beliau yang membuka pemukiman Lalang tersebut. Wilayah Kecamatan Medan Sunggal masuk ke dalam wilayah kota Medan pada tahun 1974 dan pada tahun 1991 Kecamatan Medan Sunggal dipecah jadi beberapa bagian dan di antaranya Kelurahan Lalang termasuk bagian wilayah Medan Sunggal. Selain itu sungai yang ada di Kampung lalang dulunya dikenal sebagai jalur transit untuk membawa hasil-hasil perkebunan seperti tembakau. Sungai ini juga mempunyai faktor yang besar untuk pertumbuhan pemukiman Kampung Lalang. Kehidupan sosial masyarakat Kampung Lalang tergolong baik, dimana warga asli yang ada mau membaur dan saling tolong menolong dengan warga pendatang dan tidak ditemukan konflik yang pernah terjadi antar masyarakatnya, walau saat ini dominasi etnis Melayu mulai berkurang namun keberadaan mereka tetap ada dan diakui.
\end{abstract}

Kata Kunci : Pemukiman, Kampung Lalang 


\section{PENDAhuluan}

Pada masa kota Medan bagian dari Wilayah Sumatera Timur, kota Medan dulunya dikenal sebagai kampung yang dihuni berbagai etnis Karo, Melayu, dan Simalungun. Etnis Karo dan Simalungun menempati daerah di sekitar dataran tinggi, sementara orang-orang Melayu menempati wilayah pesisir. Namun begitu, masuknya pengaruh kolonial Belanda yang ditandai dengan pembukaan lahan-lahan menjadi lokasi perkebunan, maka telah terjadi perubahan yang sangat signifikan dalam struktur masyarakat di Sumatera Timur termasuk masyarakat di Kota Medan. Buruh-buruh dari Cina, India, dan Pulau Jawa ketika itu didatangkan dalam jumlah besar oleh pengusahapengusaha perkebunan untuk memenuhi kebutuhan kerja. Oleh karena itu kota Medan adalah salah satu kota di Indonesia, yang tingkat penduduknya memiliki jumlah cukup besar. Dari saat kota Medan bagian dari Wilayah Sumatera Timur jumlah penduduknya meningkat dan bertambah banyak dan hingga sekarang sekarang kota Medan dijuluki sebagai kota terbesar ke-3.

Hal ini membuat Kota Medan didiami penduduk yang bukan hanya penduduk asli, melainkan para pendatang yang berasal dari luar Kota Medan. Sehingga Medan adalah salah satu kota yang heterogen akan etnis-etnisnya. Penduduk Kota Medan terdiri dari beragam suku, agama, golongan, kelas, sosial dan lainnya. Perlu disadari bahwa kehidupan manusia sekarang jauh berbeda dengan zaman dahulu. Salah satu contoh adalah, zaman dahulu manusia melakukan aktivitas hanya sekedar untuk memenuhi kebutuhan. Sedangkan yang dilakukan manusia pada zaman sekarang, selain untuk memenuhi kebutuhan, juga ditukar atau dijual guna memenuhi kebutuhan benda lainnya. Seperti yang diketahui bahwa klasifikasi mata pencaharian masyarakat tradisional telah dibagi menjadi beberapa bagian yaitu, berburu dan meramu, menangkap ikan, dan bercocok tanam. Selain berburu dan meramu, menangkap ikan juga merupakan mata pencaharian hidup masyarakat dan telah ada sejak awal keberadaan manusia di bumi. Dengan demikian tumbuh dan berkembang kehidupan 
masyarakat pemukiman, salah satu diantaranya adalah Kampung Lalang yang terdapat di Kecamatan Medan Sunggal. Kampung Lalang adalah pintu gerbang sebelah barat Kota Medan, dilintasi oleh jalan raya Lintas Sumatera. Maka dari itu daerah Kampung Lalang merupakan jalur komunikasi yang dapat menghubungkan ke berbagai tempat yang ada di Kota Medan maupun luar kota yang ada di Sumatera Utara, seperti Aceh, Binjai, Belawan, Deli Serdang dan daerah lainnya. Oleh karena itu juga kampung lalang sebagai sebuah daerah yang pesat perkembangannya di Kota Medan. Namun kepesatan perkembangan tersebut tidak diimbangi oleh tata ruang kota yang baik sehingga terkesan semrawut.

Perkembangan permukiman di daerah perkotaan tidak terlepas dari pesatnya laju pertumbuhan penduduk perkotaan baik karena faktor pertumbuhan penduduk kota itu sendiri maupun karena faktor urbanisasi. Dampak negatif urbanisasi yang telah berlangsung selama ini lebih disebabkan oleh tidak seimbangnya peluang untuk mencari nafkah di daerah perdesaan dan perkotaan. Seiring dengan pertumbuhan penduduk di daerah perkotaan, maka kebutuhan penyediaan akan prasarana dan sarana permukiman akan meningkat pula, baik melalui peningkatan maupun pembangunan baru. Selanjutnya pemenuhan akan kebutuhan prasarana dan sarana permukiman baik dari segi perumahan maupun lingkungan permukiman yang terjangkau dan layak huni belum sepenuhnya dapat disediakan baik oleh masyarakat sendiri maupun pemerintah, sehingga kapasitas daya dukung prasarana dan sarana lingkungan permukiman yang ada mulai menurun yang pada gilirannya memeberikan kontribusi terjadinya lingkungan permukiman kumuh. Mengingat begitu pentingnya mengetahui pertumbuhan dan perkembangan kehidupan sosial masyarakat dengan mengambil sampel Kampung Lalang maka peneliti merasa tertarik untuk melakukan penelitian mengenai Sejarah Pemukiman di Kampung Lalang Kota Medan.

Adapun yang menjadi perumusan masalah dalam penelitian ini adalah : 1 . Bagaimana sejarah terbentuknya Kecamatan Medan Sunggal. 2. Bagaimana perkembangan Kampung Lalang Kota Medan. 3. Bagaimana peranan sungai Kampung Lalang sebagai jalur transit. 4. Bagaimana kehidupan sosial masyarakat Kampung 
Lalang. 5. Bagaimana kehidupan ekonomi masyarakat Kampung Lalang. Sejalan dengan penelitian di atas, maka metode yang digunakan adalah menggunakan penelitian Lapangan (Field Research). Untuk memperkuat data penelitian maka dilakukan penelitian Study Pustaka (Library research) dengan mengumpulkan referensi dan literature-literatur yang berkaitan dengan Sejarah Pemukiman di Kampung Lalang Kota Medan.

\section{PEMBAHASAN}

\section{A. Sejarah Terbentuknya Kecamatan Medan Sunggal}

Kecamatan Medan Sunggal adalah salah satu Kecamatan di Kota Medan, Sumatera Utara, Indonesia. Kecamatan ini merupakan pemekaran dari wilayah Deli Serdang yang berada di sekeliling wilayah Kota Medan. Kecamatan Medan Sunggal ditetapkan sebagai kecamatan pada tahun 1973. Pada awalnya pemekaran Kota Medan hanya berlangsung sekali, akan tetapi berdasarkan luas administrasi yang sama maka melalui Surat Persetujuan Menteri Dalam Negeri Nomor 140/2271/PUOD, tanggal 5 Mei 1986, Kota Medan melakukan pemekaran Keluarahan menjadi 144 Kelurahan. Perkembangan terakhir berdasarkan Surat Keputusan Gubernur KDH Tingkat I Sumatera Utara 140.22/2772.K/1996 tanggal 30 September 1996 tentang pendetifipan 7 Kelurahan, secara administrasi Kota Medan dimekarkan kembali, dibagi atas 21 Kecamatan yang mencakup 151 Kelurahan. Berdasarkan perkembangan admnistratif ini Kota Medan kemudian tumbuh secara geografis, demografis dan sosial-ekonomis (Bappeda Kota Medan, 2012:94).

\section{B. Perkembangan Kampung Lalang}

Kampung tidak mungkin berevolusi menjadi sebuah kota jika tidak ada faktorfaktor luar yang mendukungnya, seperti ratusan kampung yang sampai sekarang tetap menjadi kampung dan tidak berevolusi menjadi sebuah kota (Azhari, 2012:43). Menurut Sinar (2011:57) mengatakan bahwa pada permulaannya hanya ada Kampung Medan (Puteri) dan Tebingtinggi serta Kesawan dan Kampung Baru, tetapi sewaktu 
Medan sudah menjadi ibukota Keresidenan Sumatera Timur tumbuhlah kampungkampung penduduk asli yang baru:
a. Kampung Petisah Hulu
b. Kampung Petisah Hilir
c. Kampung Sungai Renggas

Kampung-kampung ini dikepalai oleh seorang Kepala Kampung dibawah tilikan

Kontrolir di Labuhan. Sementara itu tumbuhlah lagi kampung-kampung yang baru yaitu Kampung Aur dan Kampung Keling.

Di dalam Bappeda Kota Medan (2012:62) setidaknya, jika merujuk kepada laporan Anderson tahun 1823, maka pada tahun tersebut daerah yang disebutnya sebagai 'Meidan' hanyalah kampung kecil dimana penduduknya hanyalah 200 orang.

Menurut Nasution (2012:10) Medan yang awalnya adalah sebuah perkampungan kecil banyak mendapat pengaruh dari kesultanan Melayu baik dalam bidang agama maupun dalam aspek kebudayaan. Begitu datang pengaruh kolonial Belanda yang ditandai dengan pembukaan perkebunan tembakau di Deli, kota Medan semakin berkembang pesat.

Kampung Lalang adalah salah satu wilayah yang terdapat di Kecamatan Medan Sunggal. Kampung Lalang merupakan pemukiman tua yang ada di Kota Medan dan hingga sekarang ini tidak sedikit kita temukan bentuk rumah yang terbuat dari papan.

Berdasarkan hasil wawancara dengan narasumber Kampung Lalang merupakan hutan dan rawa-rawa yang sangat menyeramkan dan tumbuhlah tumbuhan ilalangilalang yang mengelilingi hutan tersebut. Sering berkembangnya waktu, hutan yang sangat menyeramkan tersebut lama-kelamaan dijadikan sebagai suatu pemukiman oleh warga yang pertama sekali datang ke wilayah tersebut. Selain itu juga menerangkan bahwa sebelum wilayah ini dinamakan Kampung Lalang, wilayah ini merupakan hutan yang sangat menyeramkan dan terdapat beberapa binatang buas serta beberapa pohonpohon durian yang sangat besar. Kaki binatang buas tersebut terlihat saat turunnya 
hujan lebat yang terjadi di wilayah ini. Dan dari hasil wawancara dengan Bapak Muhammad Hatta menerangkan bahwa wilayah Kampung Lalang sebelum terjadi nya pemekaran-pemekaran terlihat sepi dan menyeramkan, dulunya wilayah ini terdapat binatang buas dan ditumbuhi dengan pohon ilalang-ilalang. Hal ini yang membuat masyarakat pada zaman dahulunya takut pergi ke wilayah ini, tetapi sekitar tahun 1800 Datuk Hitam yang berhasil menemukan kawasan Kampung Lalang ini”. Datuk Hitam berasal dari keturunan Datuk-Datuk Sunggal (Serbanyaman). Beliau adalah sosok pria yang sakti. Dan pada zaman dialah banyak ditemukan tumbuhan-tumbuhan ilalang tersebut. Dan beliaulah awalnya yang membuka sebuah perkampungan awal di wilayah tersebut. Nama perkampungan tersebut dinamakan Kampung Lahlang dengan alasan karena diwilayah tersebut banyak ditemukan tumbuhan-tumbuhan ilalang yang sangat luas.

Melihat situasi yang menyeramkan karena masih seperti hutan dan banyak ditumbuhi ilalang dan pohon-pohon durian yang besar, sehingga hal inilah yang merupakan salah satu alasan masyarakat yang tinggal di daerah tersebut pada zaman awalnya menamakan daerah ini Kampung Lalang. Menurut keterangan Bapak Subhan Fajri Harahap, SSTP MAP menerangkan bahwa kampung Lalang merupakan bagian wilayah dari Deli Serdang. Sekitar tahun 1974, terjadilah pemekaran Kota Medan. Dimana sebagian tanah dari daerah Deli Serdang dimasukkan ke wilayah Kota Medan, hal ini membuat Kecamatan Medan Sunggal termasuk ke dalam wilayah Kota Medan. Kampung Lalang yang dikenal saat ini terbagi dua yaitu Kelurahan Lalang yang berada di wilayah Kecamatan Medan Sunggal dan Desa Lalang yang merupakan wilayah Deli Serdang. Dan pada tahun 1974 resmilah Kampung Lalang masuk ke dalam wilayah Kecamatan Medan Sunggal Kota Medan.

Seiring dengan berjalannya waktu, perkembangan terakhir berdasarkan Surat Keputusan Gubernur KDH Tingkat I Sumatera Utara tanggal 30 September 1996, secara administrasi Kota Medan dimekarkan kembali, dibagi atas 21 Kecamatan yang mencakup 151 Kelurahan. Berdasarkan perkembangan administratif ini Kota Medan kemudian tumbuh secara geografis, demografis dan sosial ekonomis. 
Sekitar pada tahun 1973, terjadilah pemekaran Kota Medan. Dimana sebagian tanah dari daerah Deli Serdang dimasukkan ke wilayah Kota Medan, hal ini membuat Kota Medan terbagi ke dalam 11 Kecamatan dan 116 Kelurahan, hal ini membuat Kota Medan terbagi ke dalam 11 (sebelas) Kecamatan, salah satunya Kecamatan Medan Sunggal.

Dan setelah dibentuk beberapa Kecamatan baru tersebut, lalu dibentuklah wilayah-wilayah yang masuk ketiap Kecamatan tersebut, dahulunya wilayah tersebut dinamakan Kampung. Pada tahun 1956 kepala desa pertama diwilayah Kampung Lalang dulunya adalah Ishak (Sahak), beliau lah yang membuat nama Kampung Lalang pada zaman dulunya.

Salah satu kampung yang termasuk di Kecamatan Medan Sunggal adalah Kampung Lalang. Jadi, semenjak tahun 1973 resmilah Kampung Lalang masuk ke dalam wilayah Kecamatan Medan Sunggal Kota Medan.

Dari keterangan para informan tersebut dapat dipahami bahwa awal sejarahnya Kampung Lalang tersebut adalah dimana wilayah ini dulunya adalah hutan yang sangat menyeramkan dan didalam hutan tersebut ditumbuhi tumbuhan ilalang-ilalang serta pohon durian yang sangat besar. Hal inilah yang membuat masyarakat pada zaman dahulu takut pergi ke wilayah ini. Tetapi dengan seiring berjalannya waktu, banyak masyarakat yang mau bermukim dan tinggal di wilayah ini. Dan banyaknya masyarakat yang bermukim di wilayah tersebut diakibatkan terjadinya arus transmigrasi.

\section{Peran Sungai Kampung Lalang sebagai Pusat Tujuan}

Ketika pihak Belanda datang, dibukalah perkebunan-perkebunan di Sumatera Timur. Perkebunan-perkebunan tersebut berkembang sangat cepat. Supaya bisa mendukung pembangunan perkebunan-perkebunan, pemerintah Belanda memakai kebijakan 'pintu terbuka' dengan mendatangkan buruh-buruh dari dalam maupun luar Indonesia. Kebijakan ini mendorong rakyat dari berbagai kelompok etnik untuk berpindah ke Sumatera Timur . (Pelly, 2013:64). 
Menurut keterangan Bapak H. Muhammad Abut pada menerangkan bahwa, pada sekitar 400 tahun yang lalu Belanda datang untuk membuka perkebunan-perkebunan yang ada di wilayah Sumatera Timur. Lalu ketika itu datanglah suku Karo untuk mencari dataran rendah yang ada di Sumatera Timur dan kemudian terpilihlah Kecamatan Hamparan Perak sebagai lokasi yang ditujunya. Hal inilah yang menyebabkan terjadinya pembukaan lahan yang dilakukan Suku Melayu Karo di Kecamatan Hamparan Perak.

Bappeda Kota Medan (2012:1) menyatakan bahwa Kampung Terjun dan Hamparan Perak terletak hanya beberapa kilometer disebelah barat dan disebelahnya terdapat Suku Duabelas Kota yang dipimpim oleh Kejuruan Hamparan Perak yakni seorang Melayu Karo. Berdasarkan hal tersebut jelas dikatakan bahwa Suku Melayu Karo yang pertama datang untuk mencari dataran rendah dan membuka lahan di Hamparan Perak.

Fungsi sungai Belawan merupakan induknya sungai pada masa Sumatera Timur. Sungai ini berbelok-belok dan dapat menghubungkan satu tempat ke tempat lain termasuk Sungai yang ada di Kampung Lalang. Pada masa zaman Belanda sungai ini berkelok-kelok dan diperbaiki ketika fungsi sungai ini digunakan secara luas. Sehingga Belanda membuat sungai ini menjadi dalam dan luas sehingga tidak lagi bercabangcabang. Sungai Belawan kedalamannya sekitar 6 meter. Pada saat itu pihak Belanda tahun 1612 membuka perkebunan dan meminjam tanah kepada Kesultanan untuk menanam tembakau seperti perkebunan Bulu Cina, perkebunan Klumpang, dan perkebunan Terjun. Wilayah ini merupakan wilayah yang dipinjam Belanda kepada pihak Kesultanan Hamparan Perak. Adapun perjanjian yang dilakukan pihak Belanda dengan Kerajaan Hamparan perak pada saat itu adalah apabila habis ditanam tembakau dipulangkan kepada Kerajaan Hamparan Perak dan ditanami padi. Jadi akhirnya pada masa itu belum ada kendaraan untuk mengangkut hasil tembakau. Maka satu-satunya jalan untuk mengangkut tembakau adalah melalui sungai dengan menggunakan sampan. 
Adapun perjanjian yang ditetapkan untuk perkebunan-perkebunan (Sinar, 2011:39) dapat kita lihat disini : Tanah-tanah telah dibeli dari penduduk kampung, kadang-kadang dengan izin Sultan, tetapi kadang-kadang juga tanpa ijin Sultan. Oleh tuan-tuan kebun ada tanah-tanah diserahkan untuk perumahan, diambil dari areal yang dikonsesikan sebenarnya untuk keperluan cocok tanam.

Husny (1978:29) menyatakan bahwa Sungai Belawan kata aslinya "Bulawan" artinya adalah "Janji yang dibuat dengan sumpah, bermuara di kuala Belawan. Di sini sungai itu bernama juga Sungai Buluh Cina, dengan cabang-cabang: Sungai Pantai dan Sungai Kepala Anjing. Kampung lama di hulu Sungai Belawan adalah: Paya Geli, Asam Kumbang, Simpangtiga, Kelambir Lima, Sunggal dan lain-lain. Sungai Belawan berpangkal di gunung Dolok Pintu. Bappeda Sejarah Kota Medan (2012:62) menyatakan bahwa, hal ini kemudain memacu lahirnya kampung-kampung yang terdapat di kawasan ini khususnya disepanjang aliran Sungai Deli dan Babura yang bermuara ke Selat Malaka. Penting dicatat disini bahwa, pemukiman masyarakat pada awalnya pastilah memilih kawasan yang dekat dengan sumber-sumber air seperti sungai atau pesisir pantai dan jika memilih disekitar sungai, maka dapat dipastikan perkampungan dimaksud berada di sepanjang pesisir sungai. Hal ini kemudian memacu lahirnya perkampungan sebagai rentetan dari perkembangan kampung-kampung sepanjang jalan (pinggir sungai Deli) mulai dari Labuhan hingga ke Deli Tua.

Berdasarkan keterangan nasarumber maka dapat dinyatakan bahwa sungai pada masa Sumatera Timur merupakan arus lalu lintas suku Melayu Karo untuk mencari dataran rendah dan berdomisili di wilayah Hamparan Perak. Sungai inilah yang menghubungkan suku Melayu Karo datang dari dataran tinggi masuk ke wilayah Hamparan Perak dan sebagian lagi pergi ke arus sungai yang mengikuti sungai yang berada di Kampung Lalang. Melalui sungai inilah dapat dikatakan tumbuhnya sebuah perkampungan-perkampungan kecil dan sebagai pusat tujuan untuk mengangkut hasilhasil perkebunan seperti tembakau.

\section{Kehidupan Sosial Masyarakat Kampung Lalang}


Berdasarkan penjelasan diatas bahwa banyak masyarakat yang bermukim di wilayah ini baik itu para penduduk asli maupun penduduk pendatang. Hal ini yang membuat wilayah Kampung Lalang terjadi interaksi yang dilakukan para penduduk asli maupun penduduk pendatang baik secara individu maupun kelompok yang berdampak kepada kehidupan sosial masyarakat.

\section{Interaksi Sosial Masyarakat Kampung Lalang}

Karena pada dasarnya dalam kehidupan sosial masyarakat pondasi yang utama untuk membangun sebuah hubungan yang baik didasarkan pada norma dan nilai sosial yang berlaku di masyarakat tersebut. Berlangsungnya interaksi sosial dengan baik jika aturan-aturan dan nilai-nilai sosial yang dilakukan dengan baik. Jika tidak adanya kesadaran diri masing-masing, maka proses sosial pun tidak akan berjalan dengan yang diharapkan.

Dari hasil wawancara dengan Bapak Supono menerangkan bahwa interaksi sosial yang terajadi pada masyarakat di Kampung Lalang sangat baik. Hubungan antara suku penduduk asli dengan para pendatang dapat saling membaur dan menjalin kontak yang baik. Seperti yang dijelaskan Gunawan dalam Bonner (2000:31), interaksi sosial ialah hubungan antara dua orang atau lebih, sehingga kelakuan individu yang satu mempengaruhi, mengubah, atau memperbaiki kelakuan individu yang lain, dan sebaliknya.

Menurut Soekanto (2014:50) Interaksi sosial adalah kunci dari semua kehidupan sosial, oleh karena tanpa interaksi sosial, tak akan mungkin ada kehidupan bersama. Bertemunya orang perorangan secara badaniyah belaka tidak akan menghasilkan pergaulan hidup dalam suatu kelompok sosial. Pergaulan hidup semacam itu baru akan terjadi apabila orang perorangan atau kelompok manusia bekerja sama. Seling berbicara, dan seterusnya untuk mencapai suatu tujuan bersama, mengadakan persaingan, pertikaian dan lain sebagainya. Maka dapat dikatakan bahwa interaksi sosial adalah dasar proses-proses sosial, pengertian mana menunjuk pada hubunganhubungan sosial yang dinamis". 
Berdasarkan hasil wawancara dengan $\mathrm{Ibu} \mathrm{Hj}$. Aisyah menerangkan bahwa interaksi sosial pada masyarakat Kampung Lalang terjalin sangat baik. Karena pada umumnya mereka semua yang tinggal di Kampung Lalang masih satu keturunan yaitu keturunan Melayu Karo. Hal ini yang membuat masyarakat di Kampung Lalang hidup rukun dan damai, walaupun mereka berbeda suku dan agama tetapi menurut mereka masih satu keturunan. Pada saat Kampung Lalang belum terbagi dua, rumah atau tempat tinggal yang didiami oleh suku melayu adalah rumah yang berbentuk panggung, dindingnya masih dari papan. Menurut beliau alasan mereka membentuk rumah panggung supaya tidak terserang oleh binatang buas. Selain itu karena faktor kenyaman dan juga melihat kondisi ekonomi yang tidak memungkinkan untuk melakukan perbaikan rumah, walaupun sebagain sudah ada rumah-rumah tua yang sudah melakukan renovasi”.

Dan menurut keterangan informan, ada beberapa rumah-rumah tua yang terdapat di pemukiman Kampung Lalang, yaitu :

- Rumah Alm. H. Arsyad Umar yang terdapat di belakang pasar kampung lalang (gang balai desa) dan sampai sekarang keadaan rumah tersebut masih terjaga dengan baik. Diperkirakn rumah tua ini sudah berusia sekitar 150 tahunan.

- Rumah Bapak H. Muhammad yang terdapat di Gg Swadaya dibangun sekitar tahun 1932. Rumah ini adalah peninggalan Belanda dan digunakan sebagai tempat tinggal nyai Belanda.

- Rumah Alm H. Jakum dibangun pada tahun 1960 yang terdapat di Gg Resleting. Sampai sekarang bentuk asli rumah tersebut masih bertahan.

Dari semua hasil wawancara para informan tersebut, dapat dipahami bahwa interaksi sosial yang terjadi pada masyarakat Kampung Lalang terjalin dengan sangat baik interaksi dengan penduduk asli maupun dengan penduduk pendatang, dan hal ini juga merupakan alasan mereka untuk mau bermukim di wilayah ini. Selain itu, ada beberapa rumah-rumah tua di wilayah Kampung Lalang yang masih dipertahankan kondisi rumahnya dari dulu hingga sekarang, karena menurut mereka merasa nyaman 
dengan kondisi seperti itu dan juga melihat kondisi ekonomi yang tidak memungkinkan untuk merenovasi rumah tersebut.

Bukan hanya itu, penduduk Kampung Lalang juga terdiri atas berbagai suku bangsa antara lain Melayu, Batak, Tionghoa, dan Jawa. Tampaknya cukup besar minat warga untuk mengenal bahasa dan adat istiadat warga dari suku bangsa lainnya. Di samping itu ada warga yang merasa cukup saling menghormati, dan ada pula sedikit yang merasa perlu memperkenalkan bahasa dan adat istiadatnya kepada warga suku lainnya.

Bahasa sehari-hari antarwarga sesuku adalah bahasa suku bangsa yang bersangkutan. Akan tetapi, bahasa yang digunakan antarwarga yang suku bangsanya berbeda biasanya adalah bahasa Indonesia. Selain daripada itu, dalam lingkungan suku bangsa itu masing-masing, adat istiadat masih tampil dalam berbagai hal.

\section{Hubungan Tolong Menolong}

Kebiasaan tolong menolong masih hidup di Kampung Lalang. Menurut hasil wawancara dengan Bapak Supono pada tanggal 29 Juni 2016 mengatakan bahwa: "Warga-warga di daerah Kampung Lalang masih sangat kuat dalam hubungan tolong menolong antar tetangga. Jika terjadi kemalangan pada keluarga yang bersuku kan Jawa maka banyak warga yang saling membantu bukan hanya penduduk yang beragama islam dan suku Jawa saja yang terlibat melainkan suku-suku lainnya juga mau menolong. Sebagaian suku Tionghoa dikenal baik dalam menjaga hubungan soladaritas antar tetangga. Suku ini tidak pandang buluh dan mau membantu dan bekerjasama".

Bantu membantu masih berlangsung pula bila ada warga yang melaksanakan perhelatan/pesta, dan selamatan. Bentuk bantuan bisa berupa tenaga maupun benda. Bantu membantu yang lebih spontan terlihat jika sesuatu keluarga mengalami musibah. Soladaritas antarwarga sangat menonjol jika terjadi gangguan keamanan, seperti adanya pencurian. Semua warga laki-laki biasanya turun langsung menangkap pencuri begitu mereka mengetahui adanya kejadian itu. 


\section{E. Kehidupan Ekonomi Masyarakat Kampung Lalang}

Menurut Sinar (2011:55) menyatakan bahwa dengan datangnya kuli-kuli dari luar daerah datang berdagang dan menguji nasibnya di Sumatera Timur, maka penduduk-penduduk asli Melayu menjadi semakin terjepit. Mereka tidak tahu bersawah dan Belanda pun mengambil tanah-tanah yang baik untuk perkebunan. Orang-orang Melayu tidak mau bekerja sebagai kuli Belanda. Oleh sebab itu masalahmasalah tanah mulai muncul, terutama ketika pihak perkebunan hanya mencadangkan 4 bahu (1 bahu = 0,74 HA) tanah disekeliling kampung Melayu untuk setiap keluarga, yang tentulah tidak mencukupi.

Karena kita ketahui bahwa kebutuhan manusia itu beragam dan bersifat dinamik. Artinya kebutuhan tersebut bertambah secara kualitatif dan kuantitatif sepanjang waktu. Dan untuk memenuhi kebutuhan tersebut dibutuhkan sarana ekonominya. Sarana ekonomi disini yang dimaksud adalah alat yang digunakan manusia untuk memenuhi atau memperoleh kebutuhan sehari-harinya ataupun kebutuhan ekonominya. Seperti pasar, mall, ataupun supermarket. Pada awalnya pembentukan pemukiman Kampung Lalang, diwilayah ini hanya terdapat satu sarana ekonomi yaitu pasar Kampung Lalang. Dibangun pada tahun 1950 yang digunakan sebagai sarana kebutuhan masyarakat. tetapi seiring dengan perkembangan waktu kita dapat menemukan beragam sarana ekonomi di Kecamatan Medan Sunggal terkhusus di Kampung Lalang.

Dari hasil wawancara dengan Ibu $\mathrm{Hj}$. Aisyah mengatakan bahwa pada awal pembentukan pemukiman Kampung Lalang, kegiatan ekonomi yang dilakukan masyarakat dalam memenuhi kebutuhan hidupnya adalah dengan cara berburu dan berladang. Karena pada saat itu Kampung Lalang daerah yang berbentuk hutan dan dikelilingi tumbuhan ilalang. Tetapi pada saat Belanda datang ke wilayah tersebut, masyarakatnya dijadikan sebagai kuli di perkebunan Belanda". Sedangkan hasil wawancara dengan Bapak Supono menerangkan bahwa Kampung Lalang sebelum datangnya Belanda kawasan ini berbentuk hutan dengan ilalng-ilalangnya yang tumbuh 
dengan lebat. Karena belum terciptanya sarana ekonomi maka untuk bertahan hidup masyarakatnya banyak melakukan berburu dan berladang”.

Dari hasil wawancara para informan tersebut dapat dipahami bahwa pada awalnya masyarakat di Kampung Lalang hanya mengandalkan berburu dan berladang untuk mempertahankan kehidupannya. Pada awalnya masyarakat di Kampung Lalang belum mengenal apa itu perkerjaan dan banyak yang menjadi pengangguran sebelum adanya pasar Kampung Lalang dan sebelum pihak Belanda datang untuk membuka perkebunan. Tetapi seiring dengan perkembangan waktu, sekitar tahun 1950 dibangunlah pasar guna menciptakan lowongan perkerjaan bagi masyarakat Kampung Lalang.

Pasar Kampung Lalang merupakan pasar yang cukup besar di Kota Medan. Pasar ini telah membawa dampak yang besar bagi kehidupan sehari-hari ibu rumah tangga. Di Kampung Lalang sendiri hanya ada 10 "kedai sampai" (warung) yang selain menjual makanan juga sering menjual barang kelontong. Barang di warung itu, antara lain ialah sayuran, ikan asin, ikan basah, minyak tanah, minyak goreng, garam, gula, minuman ringan, berbagai jajan anak-anak, dan alat dapur lainnya. Biasanya pemilik "kedai sampah" berbelanja ke Pasar Kampung Lalang. Sebagian warga Kampung Lalang berbelanja secara seharian pada pagi hari ke "pajak" khususnya pasar Kampung Lalang.

\section{PENUTUP}

Dari keseluruhan uraian mengenai sejarah pemukiman di Kampung Lalang Kota Medan, penulis menyimpulkan bahwa pada awalnya wilayah Kampung Lalang adalah hutan yang sangat menyeramkan dan tumbuhnya tumbuhan ilalang-ilalang yang sangat luas. sebelum wilayah ini dinamakan Kampung Lalang, wilayah ini merupakan hutan yang sangat menyeramkan dan terdapat beberapa binatang buas serta beberapa pohonpohon durian yang sangat besar. Kaki binatang buas tersebut terlihat saat turunnya hujan lebat yang terjadi di wilayah ini. Dan dari hasil wawancara dengan Bapak Muhammad Hatta menerangkan bahwa wilayah Kampung Lalang sebelum terjadi nya 
pemekaran-pemekaran terlihat sepi dan menyeramkan, dulunya wilayah ini terdapat binatang buas dan ditumbuhi dengan pohon ilalang-ilalang.

Sungai pada masa Sumatera Timur merupakan arus lalu lintas suku Melayu Karo untuk mencari dataran rendah dan berdomisili di wilayah Hamparan Perak. Sungai inilah yang menghubungkan suku Melayu Karo datang dari dataran tinggi masuk ke wilayah Hamparan Perak dan sebagian lagi pergi ke arus sungai yang mengikuti sungai yang berada di Kampung Lalang. Melalui sungai inilah dapat dikatakan tumbuhnya sebuah perkampungan-perkampungan kecil dan sebagai pusat tujuan untuk mengangkut hasil-hasil perkebunan seperti tembakau.

Interaksi sosial yang terjadi pada masyarakat Kampung Lalang terjalin dengan sangat baik interaksi dengan penduduk asli maupun dengan penduduk pendatang, dan hal ini juga merupakan alasan mereka untuk mau bermukim di wilayah ini. Selain itu, ada beberapa rumah-rumah tua di wilayah kampung Lalang yang masih dipertahankan kondisi rumahnya dari dulu hingga sekarang, karena menurut mereka merasa nyaman dengan kondisi seperti itu dan juga melihat kondisi ekonomi yang tidak memungkinkan untuk merenovasi rumah tersebut.

Pada masa Kampung Lalang dulunya banyak masyarakat yang belum mengenal pendidikan, sehingga mereka banyak yang buta huruf. Karena pada masa itu wilayah Kampung Lalang masih berbentuk hutan yang sangat menyeramkan dengan tumbuhan ilalang-ilalang yang luas sehingga tidak memungkinkan masyarakat untuk mendirikan sarana pendidikan.

Wilayah Kecamatan Medan Sunggal masuk kedalam Kota Medan sekitar tahun 1974. Dan sejak itu pemukiman Kampung Lalang masuk ke dalam wilayah Kota Medan yaitu dibawah naungan Kecamatan Medan Sunggal. Dari segi Ekonomi pada awalnya masyarakat di Kampung Lalang hanya mengandalkan berburu dan berladang untuk mempertahankan kehidupannya. Pada awalnya masyarakat di Kampung Lalang belum mengenal apa itu perkerjaan dan banyak yang menjadi pengangguran sebelum adanya pasar Kampung Lalang dan sebelum pihak Belanda datang untuk membuka perkebunan. Tetapi seiring dengan perkembangan waktu, sekitar tahun 1950 
dibangunlah pasar guna menciptakan lowongan perkerjaan bagi masyarakat Kampung Lalang. Pada awalnya masyarakat di Kampung Lalang belum mengenal apa itu pekerjaan dan banyak yang menjadi pengangguran sebelum adanya pasar Kampung Lalang dan sebelum pihak Belanda datang untuk membuka perkebunan. Tetapi seiring dengan perkembangan waktu, sekitar tahun 1940 dibangunlah pasar guna menciptakan lowongan pekerjaan bagi masyarakat Kampung Lalang.

\section{DAFTAR PUSTAKA}

Abdurahman, Dudung. (2007). Metode Penelitian Sejarah. Yogyakarta : Ar-Ruzz Media.

Budiharjo, Eko. (1992). Sejumlah Masalah Pemukiman Kota. Bandung : Alumni.

Burke, Peter. (2015). Sejarah dan Teori Sosial. Jakarta: Yayasan Pustaka Obor Indonesia.

Daljoeni, N. (1998). Geografi Kota dan Desa. Bandung : Alumni.

Danil, Ahmad. (1992). Pengantar Sejarah dan Sejarah Sosial Ekonomi. Medan: A.C Van Oss.

Fattah, Nanang. (2003). Landasan Manajemen Pendidikan. Bandung : PT Remaja Rosdakarya.

Gottschalk, Louis. (2008). Mengerti Sejarah. Jakarta : UI Press..

Gunawan, Ary. (2000). Sosiologi Pendidikan. Jakarta : PT Asi Mahasatya.

Ihsan, Fuad. (2011). Dasar-Dasar Kependidikan. Jakarta : Rineka Cipta.

Ismawati, Esty. (2012). Ilmu Sosial Budaya Dasar. Yogyakarta: Ombak

Husny, Tengku. (1978). Lintasan Sejarah. Jakarta : Departemen Pendidikan dan Kebudayan.

Kuntowijoyo. (2003). Metodologi Sejarah. Yogyakarta : Penerbit PT. Tiara Wacana Yogya

Nasution, Fahrizal. (2012). Jejak Medan Tempo Doeloe. Medan : Penerbit Mitra.

Nuryahman, dkk. (2014). Kajian Sejarah Sosial Masyarakat Nelayan di Pesisir Wangapu Kabupaten Sumba Timur Provinsi Nusa Tenggara Timur. Yogyakarta : Penerbit Ombak Dua

Pemerintah Kota Medan. Sejarah Kota Medan. (2012). Medan : Badan Perencanaan Pembangunan Daerah Kota Medan 
Simanjuntak, Bungaran Antonius. (2015). Arti dan Fungsi Tanah Bagi Masyarakat Batak Toba, Karo dan Simalungun. Jakarta : Yayasan Pustaka Obor Indonesia.

Sinar. 2011. Sejarah Medan Tempo Doeloe. Medan : Sinar Budaya Group.

Sjamsuddin, Helius. (2007). Metodologi Sejarah. Yogyakarta : Penerbit Ombak. Soekanto, Soerjono. (2014). Sosiologi Suatu Pengantar. Jakarta : Rajawali Pers. Soeprapto. (1976). Pemukiman Manusia. Dalam Prisma No.6. Jakarta : LP3ES. Yuliati, dkk. (2003). Sosiologi Pedesaan. Yogyakarta : Pondok Pusaka Jogja.

Wirawan. (2015). Teori-Teori Sosial Dalam Tiga Paradigma. Jakarta: Prenadamedia Group. 